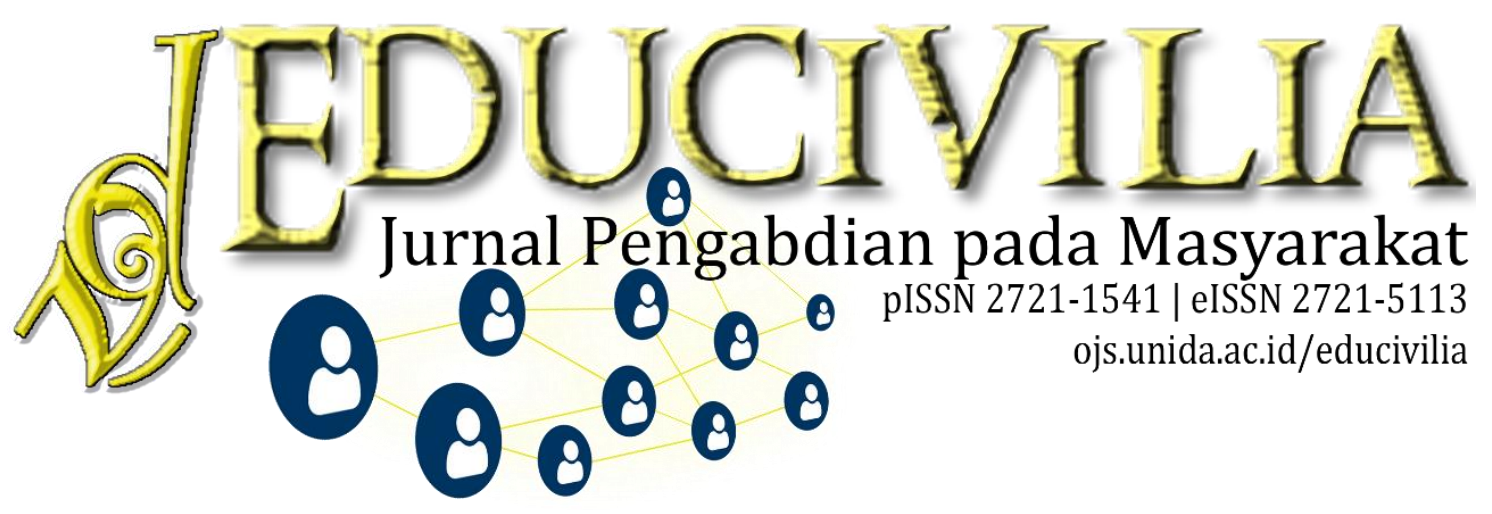

\title{
Pembentukan Karakter Siswa Selama Melakukan Pembelajaran Jarak Jauh Di Kelurahan Pamoyanan
}

\author{
Muhammad Ibnu Yasir' ${ }^{1}$, Syukri Indra ${ }^{2}$ \\ 1,2Program Studi Manajemen Pendidikan Islam, Fakultas Keguruan dan Ilmu Pendidikan, \\ Universitas Djuanda Bogor; Jl. Tol Ciawi No. 1 Kotak Pos 35 Bogor 16720
}

Kilas Artikel

Volume 2 Nomor 1

Januari 2021: 105-115

DOI:

10.30997/ejpm.v2i1.3615

Article History

Submission: $30-11-2020$

Revised: 10-01-2021

Accepted: 23-01-2021

Published: 30-01-2021

Kata Kunci:

Pembentukan

karakter,pembelajaran

jarak jauh

Keywords:

Character building, Distance learning.

Korespondensi:

(Muhammad Ibnu Yasir)

(ibnuy949@gmail.co.id)

\begin{abstract}
Abstrak
Program pembentukan karakter siswa selama melakukan pembelajaran jarak jauh di Kelurahan Pamoyanan dilatarbelakangi oleh kondisi orang tua dan masyarakat di Kampung Lembur Situ yang kurang memperhatikan pendidikan karakter terhadap anakanak, terutama selama diberlakukannya PJJ (pembelajaran jarak jauh), minimnya kesadaran untuk mengingatkan satu sama lain, sehingga sudah menjadi kebiasaan yang melekat di masyarakat dan sulit untuk merubah kebiasaan tersebut. Program ini bertujuan untuk membentuk karakter anak-anak lebih baik dari sebelumnya. Kegiatan program terbagi tiga tahap, yaitu persiapan, pelaksanaan, dan evaluasi. Menggunakan pendekatan kualitatif dengan metode deskriptif. Metode pembelajaran menggunakan metode motivasi saat pembelajaran dan pemberian contoh sikap. Bentuk motivasi saat pembelajaran berupa pemberian motivasi kepada anak-anak agar tetap semangat dalam belajar serta menanamkan karakter disela-sela pembelajaran berupa motivasi nasihat dll. Dan bentuk pemberian contoh sikap saat pembelajaran berupa memberikan contoh sikap sikap yang baik ketika berada di depan para peserta didik, seperti mengucap salam saat bertemu dan tidak menggunakan kata kata kasar saat berada diluar lingkungan pembelajar. Peserta program terdiri dari anak prasekolah, usia SD, dan SMP. Berdasarkan hasil dan evaluasi, program ini sudah cukup berhasil meningkatkan sikap sopan santun anak, walaupun masih belum bisa dikatakan program ini sudah sangat berhasil.

The Formation of Student Characters During Distance Learning In Pamoyanan Village

Abstract

The student character building program during distance learning in Pamoyanan Village was motivated by the condition of parents and the community in Lembur Situ Village who paid less attention to character education for children, especially during the implementation of PJJ (distance learning), lack of awareness to remind one another, so that it has become a habit inherent in society and it is difficult to change this habit. This program
\end{abstract}


aims to shape children's character better than before. Program activities are divided into three stages, namely preparation, implementation and evaluation. The learning method uses the method of motivation when learning and giving examples of attitudes. The form of motivation during learning is in the form of giving motivation to children to stay enthusiastic in learning and to instill character between learning in the form of motivation for advice etc. And the form of giving examples of attitudes when learning is in the form of giving examples of good attitudes when in front of students, such as saying greetings when meeting and not using harsh words when outside the learning environment. Program participants consist of preschool, elementary and junior high school children. Based on the results and evaluation, this program has been quite successful in improving children's polite attitudes, although it cannot be said that this program has been very successful.

\section{PENDAHULUAN}

Kebijakan tentang pembelajaran Tatap Muka di Sekolah maupun Kampus, masih menjadi perhatian penting di Zona yang masih terdampak Covid-19. Protokol Kesehatan yang diterapkan oleh masing-masing lembaga Sekolah maupun Kampus belum mampu menumbuhkan kepercayaan kepada masyarakat tentang efektifnya pencegahan penyebaran Covid-19. Situasi di ini mulai dirasakan oleh berbagai masyarakat. Terutama bagi para orang tua murid yang mulai kewalahan dalam mendidik anak - anaknya.

Selama proses belajar daring di rumah yang diberlakukan oleh pemerintah, Kementrian pendidikan dan Kebudayaan pun berupaya membantu meringankan beban orang tua murid dengan melakukan kerjasama dengan
Televisi Nasional melalui siaran langsung materi belajar untuk membantu siswa memahami materi dan mempermudah orang tua yang mendampingi anaknya selama pembelajaran jarak jauh berlangsung. Selain materi pendikan kognitif, siswa juga harus mengerti tentang ranah afektif yaitu watah, prilaku, minat, nilai, emosi dan lain sebagainya yang termasuk dalam pendidikan karakter sebagai manifestasi dari pelestarian budaya dan tradisi luhur bangsa: etika, moral, perilaku, akhlaq melalui berbagai nilai karakter nasionalisme, karakter integritas, karakter mandiri, karakter gotong royong yang efektif dengan metode belajar tatap muka serta pendampingan siswa.

Kebijakan dan Pengembangan pendidikan karakter ini menjadi prioritas, mencakup tentang prioritas 
pendidikan karakter berdasarkan nilai kognitif yang sifatnya moral dan akhlaq, yang diimplementasikan dalam perilaku sehari-hari.

Fakta lapangan yang menjadi kritik terhadap berbagai kebijakan tentang penanganan pembelajaran jarak jauh (daring), terkait dengan persoalan kemampuan para ibu dalam mendampingi, mengawasi serta memfasilitasi putra-putrinya belajar di rumah, dengan rutinitas yang padat sekaligus menjadi pendidik dalam situasi gempuran pandemi yang memukul berbagai sektor pendidikan termasuk juga penurunan ekonomi keluarga, sehingga harus memikirkan dampak ekonomi, menekan pengeluaran semaksimal mungkin, serta mencari solusi menyeimbangkan pemasukan.

Keluhan dan kritik para ibu ini menjadi catatan evaluasi yang harus dicari solusi terbaiknya, karena situasi pandemik yang relatif lama serta menuntut kesabaran, serta daya juang yang kuat. Faktanya, anak didik sulit untuk dikendalikan, diarahkan, dipantau untuk mengerjakan berbagai tugas beruntun yang membosankan, monoton, tidak menarik dari para guru melalui media daring. Seringkali fakta ini diabaikan oleh para pendidik yang tidak berhadapan langsung dengan para siswa. Tekanan ini, dirasakan para ibu juga para siswa. Banyak pakar berbicara tentang pentingnya inovasi para guru dalam membentuk karakter di era pandemi, tetapi sedikit dan jarang yang berupaya melihat bagaimana alih fungsi ini dilakukan oleh orang tua murid. Bagaimana mengatasi keterbatasan orang tua dari berbagai hal.

\section{METODE}

Pendekatan yang digunakan dalam penelitian ini yaitu pendekatan kualitatif dengan metode deskriptif. Program pembentukan karakter ini dilaksanakan di Kelurahan Pamoyanan, Kampung Lembur situ

Program pembentukan karakter ini dilaksanakan menjadi tiga tahapan: 1 . Pemberian motivasi atau nasihat ketika belajar, 2. Pemberian contoh sikap sehari-hari, dan 3. evaluasi.

\section{A. Motivasi Belajar}

Pada tahap motivasi belajar ini kita melakukan observasi lapangan terlebih dahulu untuk mengetahui apa yang di butuhkan oleh masyarakat.

Setalah melakukan observasi dan menentukan sasarannya, barulah kita melaksanakan kegiatan yang terdiri 
dari, proses pemberian motivasi ketika kita mendampingi anak yang sedang melaksanakan proses belajar daring, pengerjaan tugas dan mengajar pengajian.

Pemberian motivasi belajar juga kita tujukan agar anak-anak dikampung lembur situ ini dapat terdorong untuk memiliki kemauan belajar yang tinggi, karena yang dilihat di lapangan anakanak disana lebih suka bermain gadget ketimbang belajar, apalagi disaat pembelajaran jarak jauh yang mulai membosankan bagi mereka.

Disaat pembelajaran itu berlangsung kita sisipkan motivasi-motivasi ataupun nasihat-nasihat kepada anak anak, agar bisa membentuk karakternya sedikit demi sedikit.

\section{B. Pemberian contoh sikap}

Dalam tahap ini, memberikan contoh sikap yang baik ketika berada di depan para peserta didik, baik di tempat mengajar ataupun saat di luar tempat mengajar, seperti mengucap salam saat bertemu dan tidak menggunakan katakata kasar saat berada diluar lingkungan pembelajar.
Dan diharapkan dengan adanya program ini bisa meningkatkan motivasi belajar, kebiasaan anak tata bahasa anak yang membaik dan sopan terhadap orang yang lebih tua ataupun teman sebayanya bahkan yang lebih muda dari mereka.

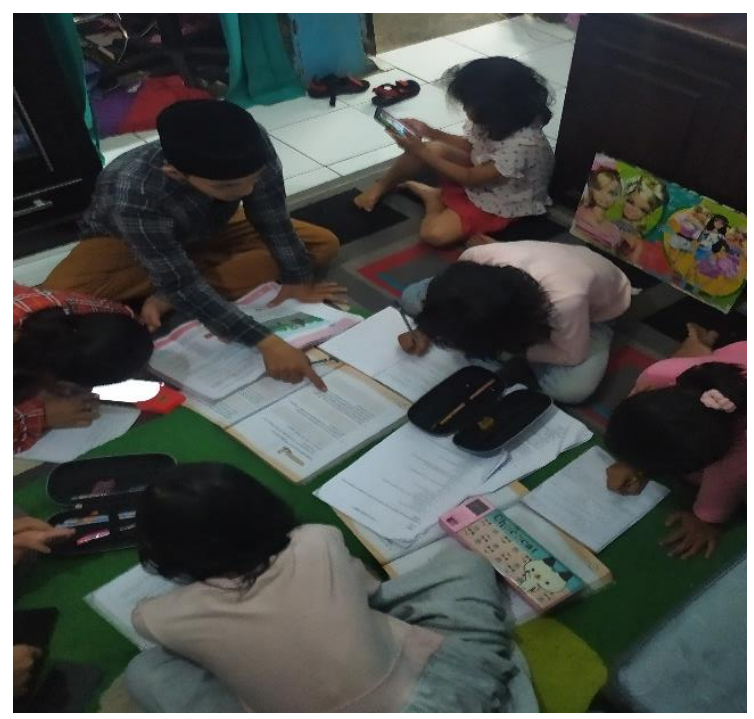

Gambar 1 Home visit

\section{Evaluasi selama menjalankan \\ Program}

Tahap evalusi ini ialah untuk mengetahui apakah selama berjalannya program ini ada perubahan yang signifikan terhadap anak-anak yang berada di Kampung Lembur situ. Bentuk evaluasi dilakukan dengan cara observasi dan wawancara. Wawancara secara langsung kepada orang tua anakanak untuk mengetahui apakah ada perubahan secara signifikan terhadap anak-anaknya atau tidak. Observasi dilaksanakan bertujuan untuk 
mengetahui bagaimana perkembangan karakter anak-anak setempat setelah program yang kita dilaksanakan dalam waktu kurang lebih satu bulan.

\section{HASIL \& PEMBAHASAN}

Proses pembelajaran di Kelurahan Pamoyanan menerapkan pembelajaran jarak jauh setelah terjadi pandemi Covid-19. Pada pelaksanaannya hampir rata-rata guru yang mengajar kepada para peserta didik di Kampung Pamoyanan dari SD sampai SMA masih memanfaatkan media Whatssapp Group sebagai media belajar agar interaksi pembelajaran antara siswa dengan guru tetap ada. Covid-19 sangat mempengaruhi kehidupan manusia di berbagai negara di dunia mulai dari sosial, budaya, ekonomi, politik, bahkan dunia pendidikan. Sisi lain hadirnya musibah ini membuat repot, tapi di sisi lainnya menghadirkan pengetahuan dan kecakapan-kecakapan baru bagi umat manusia khususnya di bidang IT. Dunia pendidikan di Indonesia pun harus merubah haluan selama pandemic covid-19 yang mengharuskan guru dan siswa mengajar-belajar dari rumah. Maka setiap guru diberi kebebasan menerapkan berbagai media agar hak-hak belajar siswa tetap tersampaikan. Hanya saja nilai-nilai Pendidikan karakter bagi peserta didik di Kelurahan Pamoyanan selama menggunakan pembelajaran online harus tetap dikawal dan dijaga oleh seluruh komponen sekolah dan Orang tua.

\section{A. Motivasi Belajar}

Istilah motivasi berasal dari kata motif yang dapat diartikan sebagai kekuatan yang terdapat dalam diri individu yang menyebabkan individu tersebut bertindak atau berbuat (Sofyan, 2004). Dikatakan pula bahwa motivasi tidak dapat diamati secara langsung tetapi dapat diinterpretasikan dalam tingkah laku yang berupa rangsangan, dorongan atau pembangkit tenaga munculnya suatu tingkah laku tertentu. Motivasi akan mendorong keberhasilan siswa menyelesaikan belajarya baik dalam proses maupun hasil belajarnya. Selain itu, menurut Slameto (1988) motivasi adalah sebagai pendorong manusia untuk berbuat agar tujuan untuk memenuhi kebutuhan, kegiatan tersebut dilakukan secara kolektip.

Motivasi merupakan hasrat untuk belajar individu. Secara umum dapat dikatakan bahwa motivasi merujuk kepada seluruh proses bergerak yang 
Pembentukan Karakter Siswa Selama Melakukan Jarak ...

mendorong dan timbul dari dalam diri individu, tingkah laku yang ditimbulkan oleh situasi tersebut dan tujuan akhir dari gerakan atau perbuatan. Dengan peranan seperti itu maka motivasi belajar menjadi faktor yang sangat penting bagi siswa, guna mencapai hasil belajar yang optimal (Sardiman, 1988). Melihat teori motivasi tersebut terlihat bahwa aktifitas yang termotivasi berarti tingkah laku mereka diarahkan pada pencapaian tujuan yang memberi kepuasan tertentu dan di mana perbuatan itu didasarkan pada adanya kebutuhan sebagai faktor pendorong

Berangkat dari teori-teori motivasi tersebut di atas, dapat dikatakan bahwa motivasi merupakan suatu dorongan yang timbul oleh adanya rangsangan dari dalam maupun dari luar sehingga seseorang berkeinginan untuk mengadakan perubahan tingkah laku tertentu yang lebih baik dari sebelumnya.

\section{B. Pembentukan karakter}

Karakter adalah cara berpikir dan berperilaku yang menjadi ciri khas tiap individu untuk hidup dan bekerjasama, baik dalam lingkup keluarga, masyarakat, bangsa dan negara.
Individu yang berkarakter adalah individu yang bisa membuat keputusan dan siap mempertanggungjawabkan tiap akibat dari keputusan yang ia buat. Jika dikaitkan dengan dunia pendidikan, karakter siswa yang baik adalah karakter siswa yang menunjukkan bahwa dirinya seorang pelajar yang berpendidikan. Anak yang terpelajar dan terdidik melalui proses pembelajaran dan pendidikan yang baik tentu saja akan menghasilkan anak yang berkarakter baik. Mereka akan mempunyai watak yang jujur, disiplin, bertanggung jawab, sopan santun, peduli terhadap orang lain, tidak sombong, mampu menghargai karya orang lain, memiliki daya kreatif tinggi. Kita atau siapapun orang lain akan bisa membedakan karakter seseorang orang yang terdidik dan tidak terdidik dari pola pikir dan perilakunya, tata tutur pembicaraannya, tindak tanduknya, tata rias/pakaiannya dan lain lain.

Menurut sumber dari Balitbang, Kementerian Pendidikan Nasional, bahwa ruang lingkup nilai moral dalam rangka pembentukan karakter yang harus dikembangkan di lingkungan keluarga adalah sebagai berikut (1) Religius: Sikap dan perilaku yang patuh 
dalam melaksanakan ajaran agama yang dianutnya, toleran terhadap pelaksanaan ibadah agama lain, dan hidup rukun dengan pemeluk agama lain; (2) Jujur: Perilaku yang didasarkan pada upaya menjadikan dirinya sebagai orangselalu dapat dipercaya dalam perkataan, tindakan, dan pekerjaan; (3) Toleransi: Sikap dan tindakan yang menghargai perbedaan agama, suku, etnis, pendapat, sikap, dan tindakan orang lain yang berbeda dari dirinya; (4) Disiplin: Tindakan yang menunjukkan perilaku tertib dan patuh pada berbagai ketentuan dan peraturan; (5) Kerja Keras: Perilaku yang menunjukkan upaya sungguh-sungguh dalam mengatasi berbagai hambatan belajar dan tugas, serta menyelesaikan tugas dengan sebaik-baiknya; (6) Kreatif: Berpikir dan melakukan sesuatu untuk menghasilkan cara atau hasil baru dari sesuatu yang telah dimiliki; (7) Mandiri: Sikap dan perilaku yang tidak mudah tergantung pada orang lain dalam menyelesaikan tugas-tugasnya;

Demokratis: Cara berfikir, bersikap, dan bertindak yang menilai sama Hak dan kewajiban dirinya dan orang lain; (9) Rasa Ingin Tahu: Sikap dan tindakan yang selalu berupaya untuk mengetahui lebih mendalam dan meluas dari sesuatuyang dipelajarinya, dilihat, dan didengar; (10) Semangat Kebangsaan: Cara berpikir, bertindak, dan berwawasan yang menempatkan kepentingan bangsa dan negara di atas kepentingan diri dan kelompoknya; (11) Cinta Tanah Air: Cara berfikir, bersikap, dan berbuat yang menunjukkan kesetiaan, kepedulian, dan penghargaan yang tinggi terhadap bahasa, lingkungan fisik, sosial, budaya, ekonomi, dan politik bangsa; (12) Menghargai Prestasi: Sikap dan tindakan yang mendorong dirinya untuk menghasilkan sesuatu yang berguna bagi masyarakat, dan mengakui, serta menghormati keberhasilan orang lain;

Bersahabat/Komuniktif: Tindakan yang memperlihatkan rasa senang berbicara, bergaul, dan bekerja sama dengan orang lain; (14) Cinta Damai: Sikap, perkataan, dan tindakan yang menyebabkan orang lain merasa senang dan aman atas kehadiran dirinya; (15) Gemar Membaca: Kebiasaan menyediakan waktu untuk membaca berbagai bacaan yang memberikan kebajikan bagi dirinya; (16) Peduli Lingkungan: Sikap dan tindakan yang selalu berupaya 
mencegah kerusakan pada lingkungan alam di sekitarnya, dan mengembangkan upaya-upaya untuk memperbaiki kerusakan alam yang sudah terjadi; (17) Peduli Sosial: Sikap dan tindakan yang selalu ingin memberi bantuan pada orang lain dan masyarakat yang membutuhkan; (18) Tanggung Jawab: Sikap dan perilaku seseorang untuk melaksanakan tugas dan kewajibannya, yang seharusnya dia lakukan, terhadap diri sendiri, masyarakat, lingkungan (alam, sosial dan budaya), negara dan Tuhan Yang Maha Esa

C. Pembelajaran Jarak Jauh

Pembelajaran daring/jarak jauh dengan melalui bimbingan orang tua. Menurut Isman pembelajaran daring merupakan pemanfaatan jaringan internet dalam proses pembelajaran. Dengan pembelajaran daring siswa memiliki keleluasaan waktu belajar, dapat belajar kapanpun dan dimanapun. Siswa dapat berinteraksi dengan guru menggunakan beberapa aplikasi seperti classroom, video converence, telepon atau live chat, zoom maupun melalui whatsapp group. Pembelajaran ini merupakan inovasi pendidikan untuk menjawab tantangan akan ketersediaan sumber belajar yang variatif.

Menurut Vicky dan Putri (Wicaksono \& Rachmadyanti, 2016) Penyelenggaran google classroom di sekolah dasar tanpa menyampingkan pembelajaran konvensional yang dilakukan. Hal ini merupakan kelebihan blended learning, dimana menggabungkan dua metode pembelajaran konvensional dan daring untuk membuat siswa merasa nyaman dan aktif dalam mengonstruksi pengetahuannya.

Menurut Heru Purnomo dalam pikiran rakyat media network pembelajaran jarak jauh dengan penerapan metode pemberian tugas secara daring bagi para siswa melalui whatsapp grup dipandang efektif dalam kondisi darurat karena adanya virus corona seperti sekarang ini. Banyak guru mengimplementasikan dengan cara-cara beragam belajar di rumah, dari perbedaan belajar itu basisnya tetap pembelajaran secara daring. Ada yang menggunakan konsep ceramah online, ada yang tetap mengajar di kelas seperti biasa tetapi divideokan kemudian dikirim ke aplikasi whatsapp siswa, ada juga yang memanfaatkan kontenkonten gratis dari berbagai sumber. 
Menurut Putra Wijaya dalam (Suryawan, 2020) belajar dirumah tidak menjadi masalah karena pembelajaran bisa dilakukan kapan dan dimana saja, apalagi sudah ada didukung dengan sistem daring. Jadi proses pembelajaran bisa terjadi di rumah, di sekolah maupun di masyarakat. Oleh karena itu semua bisa berjalan dengan baik, dengan dukungan fasilitas seperti internet.

Menurut Agus, dkk dalam penelitiannya yang berjudul "Studi Eksploratif Dampak Pandemi COVID19 Terhadap Proses Pembelajaran Online di Sekolah Dasar" dampak COVID-19 terhadap proses pembelajaran online di sekolah dasar berdampak terhadap siswa, orang tua dan guru itu sendiri. Beberapa dampak yang dirasakan murid yaitu murid belum ada budaya belajar jarak jauh karena selama ini sistem belajar dilaksanakan adalah melalui tatap muka, murid terbiasa berada di sekolah untuk berinteraksi dengan temantemannya, bermain dan bercanda gurau dengan teman-temannya serta bertatap muka dengan para gurunya, dengan adanya metode pembelajaran jarah jauh membuat para murid perlu waktu untuk beradaptasi dan mereka menghadapi perubahan baru yang secara tidak langsung akan mempengaruhi daya serap belajar mereka. Dampak terhadap orang tua yaitu kendala yang dihadapi para orang tua adalah adanya penambahan biaya pembelian kuota internet bertambah, teknologi online memerlukan koneksi jaringan ke internet dan kuota oleh karena itu tingkat penggunaaan kuota internet akan bertambah dan akan menambah beban pengeluaran orang tua. Dampak yang dirasakan guru yaitu tidak semua mahir menggunakan teknologi internet atau media sosial sebagai sarana pembelajaran, beberapa guru senior belum sepenuhnya mampu menggunakan perangkat atau fasilitas untuk penunjang kegiatan pembelajaran online dan perlu pendampingan dan pelatihan terlebih dahulu. Jadi, dukungan dan kerjasama orang tua demi keberhasilan pembelajaran sangat dibutuhkan. Komunikasi guru dan sekolah dengan orang tua harus terjalin dengan lancar.

\section{SIMPULAN}

Motivasi mengacu pada suatu proses diinisiasikannya dan dipertahankannya aktifitas yang 
Pembentukan Karakter Siswa Selama Melakukan Jarak ...

diarahkan pada pencapaian tujuan. Motivasi mempengaruhi semua aktifitas kelas, karena motivasi dapat mempengaruhi pembelajaran prilaku baru dan kinerja prilaku serta pembelajaran dan berbagai tindakan diri dapat mempengaruhi motivasi melaksanakan tugas berikutnya. Pembangunan motivasi haruslah disesuaikan dengan tujuan yang ingin dicapai. Bila mengarah pada kegiatan apresiasi maka motivasi harus dibangun atas dasar pemahaman apresiasi dalam sebuah tampilan

Dampak dari COVID-19 terhadap implementasi pembelajaran daring di sekolah dasar dapat dilakukan dengan baik. COVID-19 begitu besar dampaknya bagi pendidikan untuk memutus rantai penularan pandemik COVID-19 pembelajaran yang biasanya dilakukan di sekolah sekarang menjadi belajar di rumah dengan menggunakan berbagai macam aplikasi seperti ruang guru, class room, zoom, google doc, google from, maupun melalui grup whatsapp. Kegiatan belajar dapat berjalan baik dan efektif sesuai dengan kreatifitas guru dalam memberikan materi dan soal latihan kepada siswa, dari soal-soal latihan yang dikerjakan oleh siswa dapat digunakan untuk nilai harian siswa.

Selain materi pendidikan kognitif, siswa juga harus mengerti tentang ranah afektif yaitu watah, prilaku, minat, nilai, emosi dan lain sebagainya yang termasuk dalam pendidikan karakter sebagai manifestasi dari pelestarian budaya dan tradisi luhur bangsa: etika, moral, perilaku, akhlaq melalui berbagai nilai karakter nasionalisme, karakter integritas, karakter mandiri, karakter gotong royong yang efektif dengan metode belajar tatap muka serta pendampingan siswa.

\section{DAFTAR PUSTAKA}

Sofyan, Henninarto, dkk. (2004). Teori Motivasi dan Aplikasinya dalam Penelitian. Gorontalo: Nurul Jannah. Imaji, VolA, N

Slameto. (1988). Belajar dan Faktor-faktor yang Mempengaruhinya. Yogyakarta: PT. BinaAksara.

Sardiman, A.M. (1988). Interaksi dan Motivasi Belajar Mengajar. Jakarta: Rajawali Press.

Wicaksono, V. D., \& Rachmadyanti, P. (2016). Pembelajaran Blended Learning melalui Google Classroom di Sekolah Dasar. Seminar Nasional Pendidikan PGSD UMS \& HDPGSDI Wilayah Timur.

Suryawan, O. (2020). Guru Diminta Aktif Awasi Pembelajaran Daring Agar Siswa Tetap Fokus. BBALIPUSPANEWS.COM.

Tim Penyusun. (2011). Bahan Pelatihan Penguatan Metodologi Pembelajaran 
Berdasarkan Nilai-nilai Budaya untuk Membentuk Daya Saing dan Karakter Bangsa, Jakarta: Pusat Kurikulum, Balitbang Kemendiknas Kemendiknas.

Purwanto, A., Pramono, R., Asbari, M., Hyun, C., Wijayanti, L., Putri, R., \& santoso, priyono. (2020). Studi Eksploratif Dampak Pandemi COVID19 Terhadap Proses Pembelajaran Online di Sekolah Dasar. 